\title{
VÁCLAV MAREK
}

Associate Professor Václav Marek is one of the Czech Republic's leading experts on ancient (esp. Roman) history. However, he reached his destination field of study by a rather indirect route. After finishing his schooling in Trhové Sviny, in South Bohemia, Marek started reading Latin and Czech philology at the Faculty of Arts at Charles University in 1958, but from the very beginning his interests lay in ancient history, namely that of Ancient Greece. It was only natural that he chose a topic from Ancient Greek history for his thesis. After graduating in 1963, he embarked on the path to an academic career as an associate lecturer. Marek obtained his lower-level doctorate (PhDr.) in 1968 and in 1984 was awarded a higher-level doctoral degree (CSc.) in history. In 1988, he was appointed as an Associate Professor in Ancient History.

Between 1994 and 2000, Václav Marek proved his abilities as Deputy Head of the Institute of Greek and Latin Studies. Given his organisational skills and personal qualities, he then became the Head of the Institute in 2000, and remained in the position until 2005. Afterwards, he resumed his previous office as Deputy Head again from 2005 to 2007. Respecting, listening and considering productive suggestions made by his co-workers those are the rules by which Marek has always abided.

In line with the focus of his teaching work, Marek's research interests have lain in Roman history, especially that of the Roman Republic, from the very beginning. Other fields of his research interest include ancient numismatics and epigraphy. Back in the 1970s, the rare university collections of coins and inscriptions were not very well known among scholars and Marek was the first custodian to publish two outstanding monographs on them: Greek and Latin Inscriptions on Stone in the Collection of Charles University (Prague 1977); Roman Republican Coins in the Collection of Charles University (Prague 1985). Also Marek's study Založení ř́mské kolonie Narbo Martius: numismatická a literární evidence (Foundation of the Roman Colony of Narbo Martius: Numismatic and Literary Evidence, Graecolatina Pragensia 11, 1987, 23-48) was published to critical acclaim. His articles Some Irregular Roman Republican Coins From the Collection of Charles University (Graecolatina Pragensia 9, 1984, 75-78) and První ražba C. Iulia Caesara a smysl jejich typů (First C. Julius Caesar's Coins and the Meaning of Their Types, Acta Universitatis Carolinae Philosophica et Historica 1993/1 [= Z pomocných věd historických 11, Numismatica], 9-19) were also great scientific contributions towards research in this field. An impressive number of critical reviews of both local and international publications, together with a number of reports on Czech and international scientific production, show the huge scope of Marek's research activity. 
Václav Marek proved himself an outstanding philologist in his still unsurpassed text-critical edition M. Tulli Ciceronis Scripta quae manserunt omnia. Fasc. 16: De lege agraria orationes III, Pro Rabirio perduellionis reo oratio (Lipsiae, Bibliotheca Teubneriana 1983), and in other text-critical and philological studies. Cicero and his work have always been Marek's focus and he has never failed to come up with inspiring interpretations of difficult passages in Cicero's writings that are significant for interpreting a given work and that are a matter of dispute among scholars. A translation of Cicero's letters (M. Tullius Cicero, Listy prátelüm I. [Letters to Friends I.], Prague 2001) is another product of Marek's research efforts; the translation is supplied with an extensive preface containing many factual notes and detailed comments.

Other important works include a monograph on Roman life and institutions Ǩím Marka Aurelia (The Rome of Marcus Aurelius, Prague 1990; with R. Hošek) and Encyklopedie dějin starověku (Encyclopaedia of the Ancient World, Prague 2008; with P. Oliva and P. Charvát).

Václav Marek also co-authored a number of other publications acclaimed by peers and the public, such as Moudrost věkư. Lexikon latinských výrokü, přísloví a rčení (Wisdom of Ages. Lexicon of Latin Quotations, Sayings and Proverbs, Prague 2002; with E. Kutáková and J. Zachová) or Slovník latinských spisovateli (Dictionary of Latin Authors, Prague 2004; Marek authored the entries on Roman historians). Apart from the above-mentioned translation of Cicero's Letters, one cannot omit Marek's translations of the Lives of Eminent Generals (Životopisy slavných vojevůdcu) by Nepos, Epitome of Military Science (Nárys vojenského uměni) by Vegetius or Stratagems (Válečné lsti) by Frontinus. We must also mention his forewords to translations of important writings by Ancient historians, especially to several volumes of Livy's History of Rome.

Teaching, closely tied to his research, makes up a substantial portion of Václav Marek's academic work. It creates a natural bond between him and students reading his field or related fields taught at the faculty, and it is a basis of very friendly cooperation with all his colleagues in the Institute. His long-time cooperation with the Faculty of Arts at Západočeská univerzita in Pilsen also proved very effective. Thanks to the prominence given to it by Associate Professor Marek in his lectures and seminars, ancient history is part of the broader context of historical disciplines taught at the Faculty of Arts, Charles University. As for lecturing in his own field, let us mention Marek's introduction to general issues of research and elementary ancient history lectures and seminars for students of classical philology and ancient history \& culture. Building on these foundations, Associate Professor Marek could then continue with a range of specialized lectures and seminars on eminent historical figures or events, on topics dealing with ancient religion, moral philosophy, state and law, or life and institutions. These include seminars on numismatics and epigraphy, often attended by students of classical archaeology. All of this is complemented by thorough and level-headed supervision of undergraduate theses, and lately also very successful supervision of doctoral dissertations, both in his field and in classical archaeology. One can feel Marcus Tullius Cicero's way of work, speech and scope of activity in Marek's captivated, committed and compelling lecturing on Roman history, and on its critical moments during the Roman Republic and Roman Empire periods in particular. 
Marek's affection for his field of study is reflected in his nurturing of the further development of the ancient history field. He has been a member of the ancient history postgraduate board and has supervised postgraduate students, some of whom have become new Ancient History department staff members at the Institutum Graecitati at Latinitati augendae (Institute of Greek and Latin Studies). Marek's efforts and systematic care were crowned by accreditation of a new undergraduate (BA, MA) program Ancient Civilization History \& Culture in 2013.

Writing university textbooks is an integral part of a university teacher's work. Let us mention at least some titles from the long list of textbooks authored or co-authored by Marek: Úvod do studia latiny (Introduction to Latin Studies, Prague 1977; with R. Hošek) and Archaický Řím. Výběr z odborné literatury k počátkům římského státu (Archaic Rome. Anthology of Scientific Literature on the Beginnings of Rome, Prague 1986), secondary- and grammar-school textbooks of history, and above all a two-volume textbook Disco Latine (Prague 1995 and 1996; with E. Kutáková and B. Mouchová). The textbook accompanies a 35-episode educational TV series of the same name and Václav Marek authored all historical sections dealing with Roman public and private life.

Marek's teaching work also includes grammar-school lecturing, public lecturing and popularization of science and, last but not least, long-standing work at the University of the Third Age, where his lectures are highly acclaimed and very popular.

Associate Professor Václav Marek has also put his academic and organisational skills to good use outside the Institute of Greek and Latin Studies - as a member of the Faculty of Arts editorial commission, as Secretary of Acta Universitatis Carolinae Philologica et Historica editorial board, as Graecolatina Pragensia editor or as the vice-chair of the Union of Classical Philologists (Jednota klasických filologů).

Diligence, responsibility, modesty, a good deal of understanding and kindness, persuasive advocacy and endorsement of important and useful views and impulses - all of these are the qualities that Václav Marek abounds in and that have brought him success in his research, teaching and popularizing work, as well as in the number of posts he has held.

Václav Marek has spent all his professional life working at the Faculty of Arts at Charles University in Prague, yet as a true South Bohemian, he has never really left South Bohemia either. It is the region of his family bonds, the region he loves for its beautiful country and as a place of repose and relaxation. We wish our dear colleague, from the bottom of our hearts, abundant spare time. However, we, his colleagues and his students, also wish that Václav Marek will also still like to stay in Prague and pursue ancient history, fit and healthy, for many years to come.

Bohumila Mouchová and Eva Kutáková 